\title{
New record of Monsonia herrei for Namibia
}

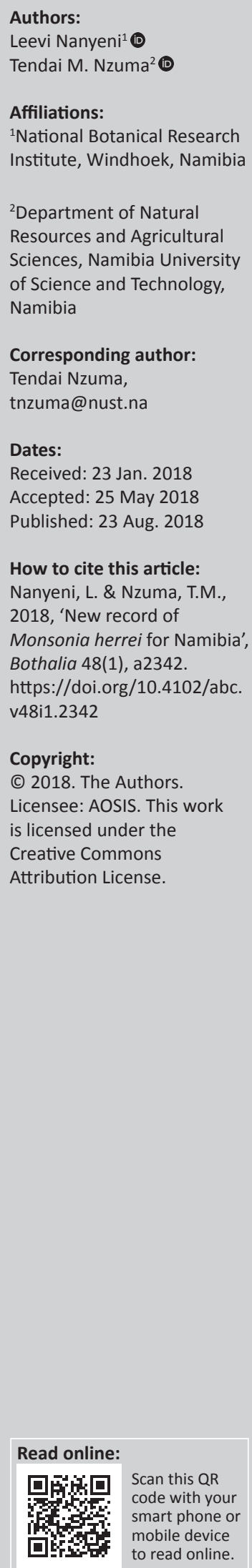

Background: The southern part of Namibia's terrain is highly inaccessible making it difficult to explore. Expeditions into difficult terrain can result in new biological discoveries for Namibia. Monsonia herrei has been recorded for South Africa, but has not previously been recorded for Namibia.

Objectives: As part of updating the biodiversity records of Namibia, we report the occurrence of a species not previously recorded for the Namibian flora.

Method: A botanical field trip was undertaken in September 2014 to the far south of Namibia in the Aussenkehr region along the Orange River. Plant identification was carried out based on herbarium vouchers, observation and photographic records. One collection constituted a new record of the species for Namibia. A voucher specimen of this new record was collected and deposited at the National Botanical Research Institute Herbarium (WIND). Plant identification was confirmed by experts on plants from the region.

Results: One species not previously recorded for Namibia, namely Monsonia herrei (L. Bolus) F. Albers, was found during the exploration of the Aussenkehr area.

Conclusions: This new record for Namibia confirms the need to update the inventory of the flora of Namibia.

\section{Introduction}

The National Botanical Research Institute of Namibia (NBRI), which houses the National Herbarium (WIND), is mandated to document the indigenous plants of the country. The National Herbarium organises about three trips annually for plant collections, mainly in under-collected areas. The southern part of Namibia is one of the country's biodiversity hotspots and includes the cross-border Gariep Centre of Endemism, shared with the Northern Cape of South Africa (Swanepoel 2011; van Wyk \& Smith 2001). Because of the inaccessibility of many places and mountainous areas, there is a wide gap in the herbarium collecting intensity of this region. Aussenkehr is known to be a biogeographical region (Swanepoel 2011; Van Jaarsveld et al. 2007) that attracts many botanists and ornithologists. Because of large climatic and topographical variability, together with the combination of both summer and winter rainfall, many annual or short-lived plant species have been missed during past botanical surveys. The mean annual rainfall is between $15 \mathrm{~mm}$ and $150 \mathrm{~mm}$ which increases along a southwest to northeast gradient, whilst the mean annual temperature increases from $16^{\circ} \mathrm{C}$ to $20^{\circ} \mathrm{C}$ along an east-west gradient (Burke 2017).

Monsonia herrei (L.Bolus) F.Albers (Geraniaceae) is a fleshy, short sub-shrub commonly known as Bushman's candle (Verhoeven, Venter \& Van Rensburg 1983). The genus Monsonia is found throughout Africa and south-west Asia, but the majority of the species occur in southern Africa (Miller 2003). Klaassen and Kwembeya (2013) record 11 species occurring naturally in Namibia. Based on the localities obtained from the National Botanical Research Institution (NBRI), the distribution of Monsonia is concentrated more in the southern part of the country (Figure 1) although a few records extend from central to north-west Namibia into the Kaokoveld Centre of Endemism, which is also botanically poorly explored (Swanepoel 2013).

\section{Methodology}

\section{Plant collection}

In September 2014, Leevi Nanyeni, Silke Rügheimer and Josophina Shaanika made an 8-day trip to the southern part of Namibia as far as the Aussenkehr area on the northern bank of the Orange River, which is part of the Richtersveld World Heritage Site. The purpose of the trip was to improve the herbarium collection intensity. 

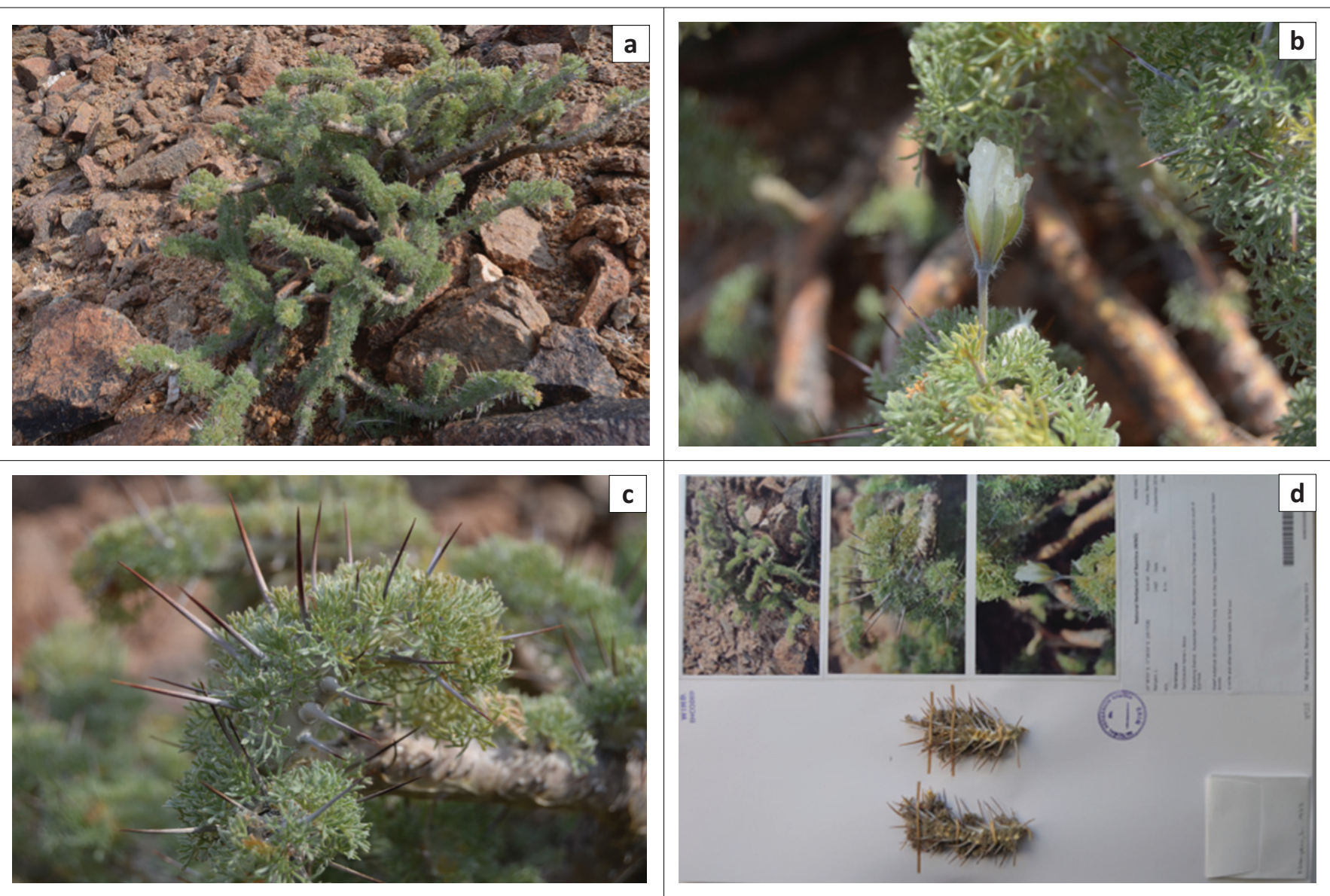

Source: Photos courtesy of Leevi Nanyeni

FIGURE 1: Monsonia herrei at Aussenkehr, Namibia: (a) habit, (b) flower, (c) spines and (d) herbarium voucher specimen.

\section{Results}

Thirty-seven plant species from 22 families and 45 genera were recorded during the trip. The survey resulted in one species being found that, according to literature and herbaria consulted, has not been previously recorded from Namibia. Besides the presence of species like Anticharis scoparia (E.Mey. ex Benth.) Hiern ex Benth. \& Hook.f., Pegolletia oxyodonta DC., Polygala virgata Thunb. var. decora (Sond.) Harv. and Jatropha orangeana Dinter ex P.G.Mey., a strange dwarf woody plant was noted. About three plants within a $50 \mathrm{~m} \times 50 \mathrm{~m}$ area were observed. The woody plant with fine leaves and sharp spines was then collected (LN 923) as Monsonia sp. (Figure 1). Anticipating that it may be a new species, pictures were sent to the WIND Herbarium to compare it with the existing collections, and the plant did not match any of the previously recorded specimens in Namibia. However, the plant was found to match the description of Moffett (1979) of M. herrei. Although the plant lacked fruits, the flowers and vegetative features were sufficient to give positive identification as Monsonia herrei. Significant diagnostic characters were the presence of the branch spines and the pale mimosa-yellow petals with scattered hairs on the adaxial surface. Although the authors based their identification on the spines and the petal indumentum, the flowering time was also a key tool in comparison, which is September to November.

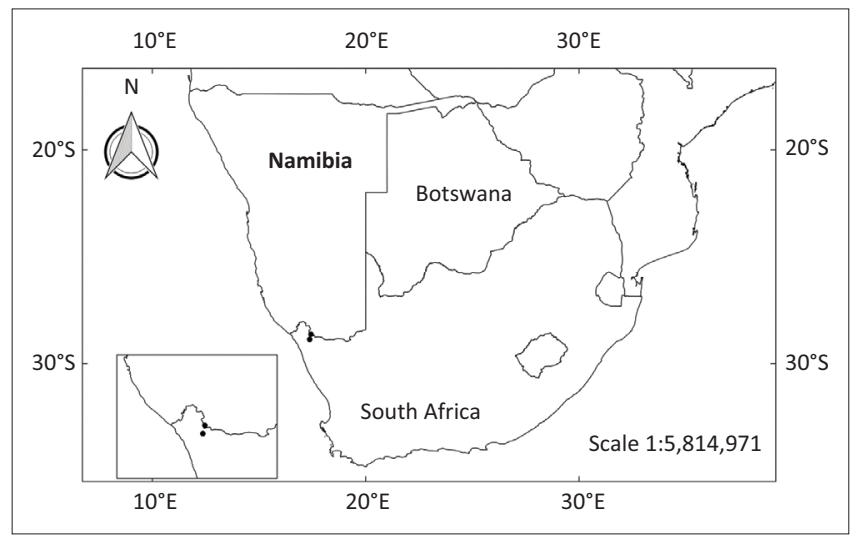

FIGURE 2: Distribution of Monsonia herrei L. in Namibia and South Africa.

Local botanists Silke Rügheimer and Coleen Mannheimer confirmed the identification of our specimen.

According to Moffett (1979), the species M. herrei, which was transferred from Sarcocaulon (DC.) Sweet to Monsonia by Albers (1996), is confined to the south-eastern Richtersveld on the South African side of the border. We now confirm the presence of $M$. herrei on the Namibian side $5 \mathrm{~km}$ south of Sjambok on the mountain ranges along the Orange River. It grows on almost loose rocky areas of granite (Figure 2). 


\section{Key specimens examined}

Namibia: 2813 (Aussenkehr): Orange River, Mountain hill south facing slope, 13 Sept. 2014, L. Nanyeni 923 (WIND).

South Africa: 2817 (Vioolsdrift): Stinkfontein, Mar. 1931, $H$. Herre 1025 (BOL); 18 miles beyond Vioolsdrift on the way to Stinkfontein, 11 May 1969, M.J.A. Werger 393 (WIND); west of Vioolsdrift, 4 Mar. 1975, R.O. Moffett $631 b$ (WIND).

\section{Discussion and conclusions}

Monsonia L. (Geraniaceae) is represented by 26 species in Africa and Madagascar (Albers \& Van der Walt 2007; Mannheimer, Marais \& Schubert 2008). Prior to 2014, 11 species were recognised to occur naturally in Namibia. We report on a new record for $M$. herrei, bringing the total to 12 species.

Monsonia herrei was previously known to occur only in the south-eastern section of the Richtersveld, Northern Cape. However, this new record shows it to occur in Aussenkehr, Richtersveld, on the Namibian side. The known South African records were found on dry rocky ridges (gneiss/ granite). Similarly, the new record was present on loose rocky granite ridges.

The collection conducted so far in the Aussenkehr area, on the Namibian side, has significantly increased our knowledge of the severely under-collected flora. Data of the complete distribution of taxa, especially taxa with limited ranges, are essential to help us fully understand these plant species. This new record for Namibia shows that the Namibian flora inventory needs to be updated.

\section{Acknowledgements}

The authors thank the Ministry of Agriculture, Water and Forestry (MAWF) for allowing them to conduct and providing all supports (vehicle, DSA and time) during the field study. They also thank Silke Rügheimer and Josophina Shaanika for their help in the field. Vanessa Stein is thanked for her technical support. Lastly, the authors are grateful to
Iain Derbyshire for reviewing the final manuscript and for his constructive comments.

\section{Competing interests}

The authors declare that they have no financial or personal relationships that may have inappropriately influenced them in writing this article. The authors have declared that any potential conflict of interest in the research and any support from a third party has been noted in the Acknowledgements.

\section{Authors' contributions}

L.N. collected the material and did most of the fieldwork in the Aussenkehr area. T.M.N. prepared the manuscript and provided additional information.

\section{References}

Albers, F., 1996, 'The taxonomic status of Sarcocaulon (Geraniaceae)', South African Journal of Botany 62(6), 345-347. https://doi.org/10.1016/S0254-6299(15)30678-5

Albers, F. \& Van der Walt, J.J.A., 2007, 'Geraniaceae', Flowering Plants Eudicots, Springer, 157-167.

Burke, A., 2017, 'New plant distribution records for southern Namibia', BothaliaAfrican Biodiversity \& Conservation 47(1), 1-6. https://doi.org/10.4102/abc. v47i1.2251

Klaassen, E.S. \& Kwembeya, E.G., 2013, 'A checklist of Namibian indigenous and naturalised plants', Occasional Contributions 5, 1-596.

Mannheimer, C., Marais, A.L. \& Schubert, S., 2008, Toxic plants of veterinary importance in Namibia, Ministry of Agriculture, Water, and Forestry, Windhoek, Namibia.

Miller, D.M., 2003, 'The taxonomy of Pelargonium species and cultivars, their origins and growth in the wild', Geranium and Pelargonium: History of Nomenclature, Usage and Cultivation 49, Chapter 8, pp. 1-31.

Moffett, R.O., 1979, 'The genus Sarcocaulon', Bothalia 12(4), 581-613. https://doi. org/10.4102/abc.v12i4.1424

Swanepoel, W., 2011, 'Commiphora buruxa (Burseraceae), a new species from southern Namibia', South African Journal of Botany 77(3), 608-612. https://doi. org/10.1016/j.sajb.2010.12.004

Swanepoel, W., 2013, 'Sapindaceae', Bothalia 43(1), 89-90. https://doi.org/10.4102/ abc.v43i1.113

Van Jaarsveld, E.J., Swanepoel, W., Van Wyk, A.E. \& Lavranos, J., 2007, 'Aloe pavelkae, a new cliff-dwelling species of Aloe series Mitriformes from southern Namibia'. Aloe 44(3), 75-79.

Van Wyk, A.E. \& Smith, G.F., 2001, Regions of floristic endemism in southern Africa: A review with emphasis on succulents, Umdaus press, Hatfield, Pretoria.

Verhoeven, R.L., Venter, H.J.T. \& Van Rensburg, W.L.J., 1983, 'Anatomy of Sarcocaulon', Bothalia 14(3/4), 895-899. https://doi.org/10.4102/abc.v14i3/4.1259 